\title{
Mikroprocesorowy układ sterowania i diagnostyki systemu pneumatycznego oraz układ wykrywania i likwidacji poślizgu zmodernizowanej lokomotywy spalinowej ST44
}

\begin{abstract}
$W$ artykule omówiono budowę $i$ dziatanie uktadu sterowania oraz przedstawiono jego schemat blokowy. Omówiono sterowanie praca sprężarki i uktadu hamowania, diagnostykę uktadu hamowania oraz komunikacje ze sterownikiem lokomotywy $i z$ komputerem serwisowym. Przedstawiono układ wykrywania i likwidacji poślizgu przy hamowaniu oraz przy jeździe, budowe układu przeciwpoślizgowego $i$ jego wspótprace $z$ poszczególnymi systemami lokomotywy, realizowane przezeń funkcje oraz algorytm działania. Przedstawiono opis prób $i$ zamieszczono przyktadowe przebiegi. Przedstawione uktady zostały przetestowane $i$ zastosowane na dwóch zmodernizowanych lokomotywach oraz wykazały poprawność działania.
\end{abstract}

\section{Wstęp}

$\mathrm{W}$ ramach modernizacji lokomotyw spalinowych ST44 wprowadzono układ sterowania i diagnostyki systemu pneumatycznego oraz układ wykrywania i likwidacji poślizgu (w skrócie: sterownik pneumatyki). Sterowanie układem pneumatycznym hamulca lokomotywy realizowane jest przez tablicę pneumatyczną, diagnozowaną przez niezależny sterownik mikroprocesorowy. Wykrywanie poślizgu przy hamowaniu i rozruchu realizowane jest przez ten sam sterownik w oparciu o sygnały z 6 czujników prędkości umiejscowionych na każdej osi lokomotywy. Likwidacja poślizgu przy hamowaniu odbywa się poprzez 4 zawory przeciwpoślizgowe (zamontowane po 2 na każdym wózku lokomotywy) odpowiednio sterowane przez sterownik [1]. Przy rozruchu wstępne zabiegi przeciwpoślizgowe (piaskowanie i podhamowanie) realizowane sa przez sterownik pneumatyki, a dalsze zabiegi przez sterownik lokomotywy.

Układ sterowania i diagnostyki systemu pneumatycznego stanowi adaptację układu zastosowanego na zmodernizowanej lokomotywie elektrycznej ET222000. Dla układu wykrywania i likwidacji poślizgu jest to pierwsze kompleksowe rozwiązanie obejmujące opracowanie i zaimplementowanie algorytmu oraz wdrożenie i uruchomienie układu sterowania na pojeździe. Sam algorytm natomiast stanowi adaptację algorytmu zastosowanego na lokomotywie ET222000.

\section{System sterowania}

Sterownik pneumatyki wchodzi w skład systemu sterowania zmodernizowanej lokomotywy, którego schemat blokowy przedstawiony jest na rys. 1 . W skład systemu sterowania wchodzą ponadto:

- sterownik główny lokomotywy
- dwa dotykowe panele operatorskie

- sterownik silnika spalinowego

- sterownik prądnicy głównej

- sterownik prądnicy pomocniczej.

Składający się z kilku modułów sterownik pneumatyki (rys. 2), konwerter RS232/RS485 oraz przetwornice napięcia $24 \mathrm{~V}$ DC (dla sterownika i wzmacniaczy sygnałów czujników prędkości) umieszczone są w szafie kabiny 1 . Za tą szafą znajduje się tablica pneumatyczna (rys. 3), z której do sterownika doprowadzone są sygnały wejściowe analogowe i cyfrowe, a ze sterownika sygnały sterujące. Natomiast wzmacniacze sygnałów z czujników prędkości umieszczone są w skrzynkach umiejscowionych na wózkach. Do każdego wzmacniacza doprowadzone są sygnały z 3 czujników prędkości, które po ukształtowaniu do sygnału prostokątnego $24 \mathrm{~V}$ podawane są na wejścia licznikowe sterownika pneumatyki.

\section{Opis układu sterownika pneumatyki}

\section{Sygnały wejściowe i wyjściowe}

Do odpowiednich wejść sterownika pneumatyki doprowadzone są następujące sygnały: 26 sygnałów cyfrowych, 3 sygnały analogowe (prądowe: $4 \div 20 \mathrm{~mA}$ ) oraz 6 sygnałów częstotliwościowych. Na podstawie stanu sygnałów wejściowych sterownik odpowiednio steruje 14 wyjściami cyfrowymi.

Wejściowe sygnały cyfrowe doprowadzone są z pulpitu (pozycja nastawnika układu hamulcowego, pozycja manipulatorów hamulca zespolonego i dodatkowego, stany przycisków piaskowania i odluźniacza hamulca, stan przełącznika hamulca postojowego), ze sprężarki (przekroczenie przez temperaturę powietrza progów $100^{\circ} \mathrm{C}$ i $115^{\circ} \mathrm{C}$ ) oraz z tablicy pneumatycznej (sygnały $\mathrm{z}$ aparatów elektropneumatycznych). 
KABINA 1

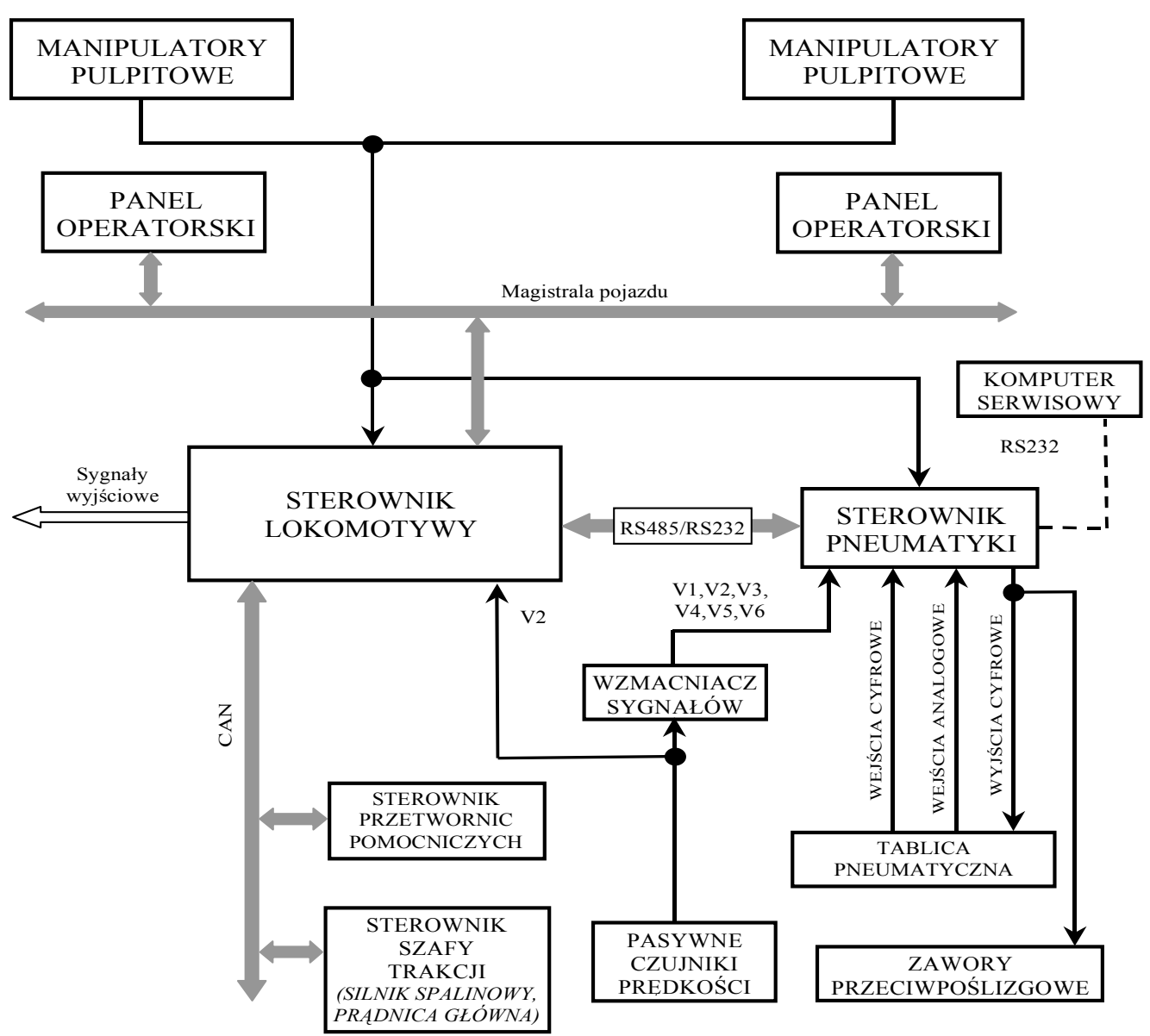

Rys. 1. Schemat blokowy systemu sterowania lokomotywą

Wejściowe sygnały analogowe doprowadzone są $\mathrm{z}$ pomiarowych przetworników ciśnień (zakres pomiarowy od 0 do 10 barów) zabudowanych na tablicy pneumatycznej (rys. 3):

- ciśnienia w przewodzie zasilającym (MS)

- ciśnienia w przewodzie głównym (MG)

- ciśnienia w cylindrach hamulcowych (MC).

Wejściowe sygnały częstotliwościowe doprowadzone są z pasywnych czujników prędkości obrotowej FE1.4 firmy DACO zamocowanych na 6 osiach lokomotywy. Czujniki te generują sygnały sinusoidalne o częstotliwości i amplitudzie zależnej od prędkości obrotowej danej osi. Sygnały te, przed doprowadzeniem na wejścia licznikowe sterownika pneumatyki, wymagają przekształcenia do sygnału prostokątnego o stałej amplitudzie 24 V DC. Realizowane jest to poprzez 3 kanałowe wzmacniacze WSL-5 (zamontowane po 1 na każdym wózku lokomotywy).

Wyjścia cyfrowe sterują pracą zaworu odluźniacza hamulca, zaworu hamulca postojowego, elektrozaworami piasecznic oraz pracą 4 zaworów elektropneumatycznych (sterujących cylindrami hamulcowymi). Jedno z wyjść podłączone na wejście sterow- nika głównego lokomotywy zostaje wysterowane, gdy sterownik pneumatyki wykryje wystąpienie poślizgu.

\section{Wspólpraca ze sterownikiem głównym lokomotywy oraz komputerem serwisowym (diagnostycznym)}

Sterownik pneumatyki posiada 2 porty RS232. Jeden z tych portów wykorzystywany jest do komunikacji ze sterownikiem głównym lokomotywy natomiast drugi do komunikacji z komputerem serwisowym.

Współpraca sterownika pneumatyki ze sterownikiem głównym lokomotywy odbywa się za pośrednictwem konwertera RS232/RS485. Sterownik pneumatyki przesyła do sterownika głównego lokomotywy informacje o wszystkich stanach wejściowych i wyjściowych oraz wybrane dane obliczone w sterowniku, natomiast zwrotnie otrzymuje informacje o stanie wybranych układów lokomotywy.

Komputer diagnostyczny $\mathrm{z}$ zainstalowanym odpowiednim oprogramowaniem umożliwia podgląd $i$ analizę poprawności działania programu, według którego pracuje sterownik pneumatyki, zmianę tego programu oraz podgląd, wizualizację i archiwizację danych diagnostycznych. 


\section{Budowa sterownika pneumatyki}

Sterownik pneumatyki (rys. 2) składa się z następujących modułów kolejowej serii MAS-T firmy Selectron Systems AG:

- 2 modułów CPU 727CT; są to moduły mikroprocesorowe $\mathrm{z} 4$ wejściami licznikowymi (częstotliwościowymi) oraz 4 wyjściami cyfrowymi

- 1 modułu AIT 704T; jest to moduł 8 wejść analogowych $0 . .20 \mathrm{~mA} \mathrm{DC}$

- 4 modułów DIT 701T; są to moduły 8 wejść cyfrowych $24 \mathrm{~V}$ DC

- 2 modułów DOT 701T; są to moduły 8 wyjść cyfrowych $24 \mathrm{~V}$ DC

- 2 modułów CTA 703T; są to rozgałęźniki typu $\mathrm{T}$ zasilania i magistrali CAN.

Moduły mikroprocesorowe połączone są ze sobą magistralą CAN, za pośrednictwem której wymieniają między sobą dane niezbędne do realizowania zaprogramowanych funkcji.

Moduly firmy Selectron Systems AG posiadają świadectwo zgodności $\mathrm{z}$ normą kolejową EN 50155:2001 [6] dotyczącą wyposażenia elektronicznego stosowanego w taborze oraz normą EN 50121-32:2000 [7] dotyczącą kompatybilności elektromagnetycznej dla zastosowań kolejowych.
SeleCAN). Moduly te mogą być rozszerzane za pomocą modułów wejść i wyjść cyfrowych i analogowych.

Znamionowe napięcie zasilania modułów wynosi $24 \mathrm{~V}$ DC, a dopuszczalne zmiany napięcia wynoszą 16,8..30 V DC. Moduły przeznaczone są do pracy w szerokim zakresie temperatur od $-25{ }^{\circ} \mathrm{C}$ do $+70{ }^{\circ} \mathrm{C}$. Dostępne są również moduły na zakres temperatur pracy od $-40{ }^{\circ} \mathrm{C}$ do $+70{ }^{\circ} \mathrm{C}$.

\section{Tablica pneumatyczna}

Sterownik pneumatyki współpracuje $\mathrm{z}$ tablica pneumatyczną (rys. 3.), integrująca wszystkie urządzenia i układy pneumatyczne lokomotywy. Aparaty pneumatyczne i elektropneumatyczne zabudowane na tablicy pneumatycznej tworzą następujące układy [3]:

- układ przewodu zasilającego z urządzeniami pośredniczącymi $\quad \mathrm{W}$ sterowaniu sprężarką główną lokomotywy

- układ sterowania hamulcem zespolonym pociagu

- układ sterowania hamulcem zespolonym lokomotywy

- układ sterowania hamulcem dodatkowym i parkingowym lokomotywy

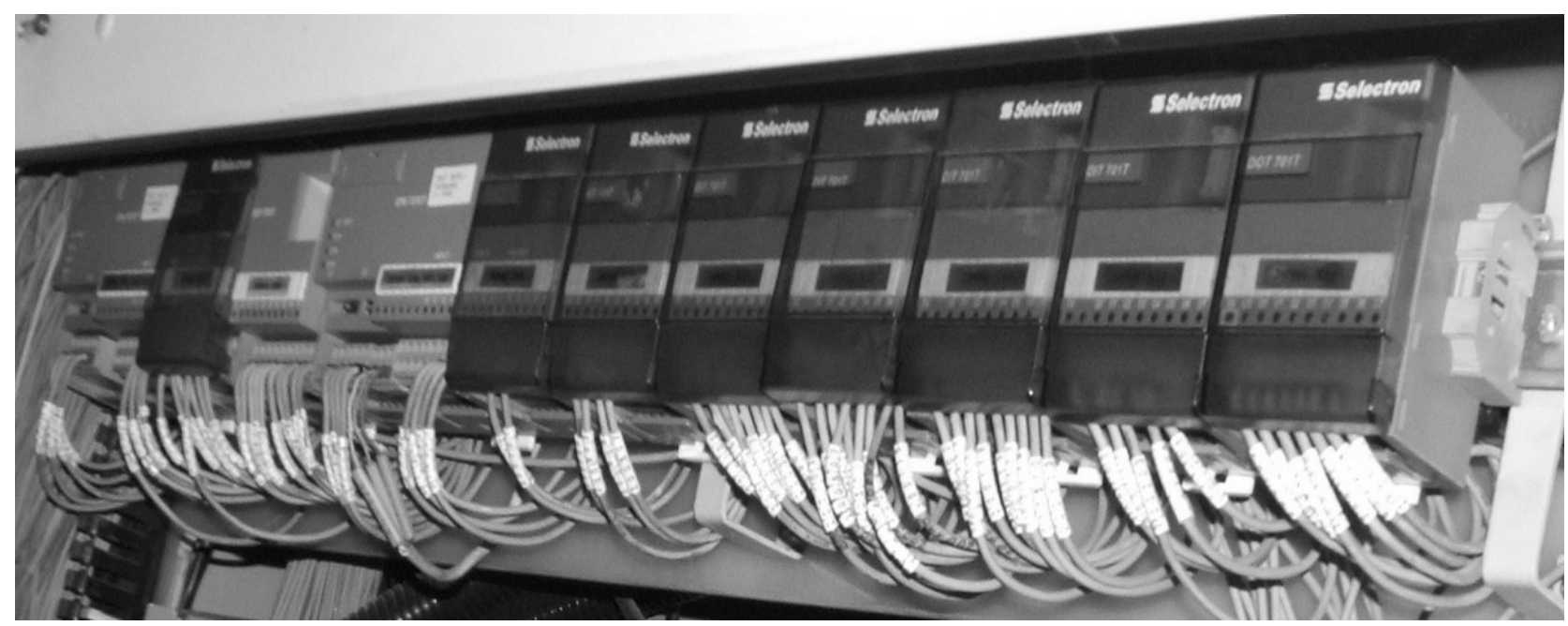

Rys. 2. Sterownik pneumatyki zmodernizowanej lokomotywy ST44

\section{Krótka charakterystyka modułów mikroproceso- rowych CPU 727CT [5]}

Moduly te oparte są na procesorze $80 \mathrm{C} 167 \mathrm{C}$, posiadają 1 MB pamięci typu FEPROM oraz $1 \mathrm{MB}$ pamięci typu RAM. Pamięć RAM podtrzymywana jest baterią litową. Moduły te wyposażone są w gniazdo do zamontowania 1 MB kasety pamięci typu FLASH.

Moduły te posiadają 1 interfejs RS 232 służący do programowania modułów lub dwukierunkowej transmisji danych oraz 1 interfejs CAN (CANopen,
- układ sterowania sprężynowym hamulcem postojowym lokomotywy

- układ pneumatyczny piasecznic

- układ zasilania zbiornika rozrządu

- układ rozrządu powietrza dla pomocniczych obwodów pneumatycznych lokomotywy.

$\mathrm{Na}$ rys. 3. zaznaczono niektóre ważniejsze aparaty elektropneumatyczne zabudowane na tablicy pneumatycznej. 


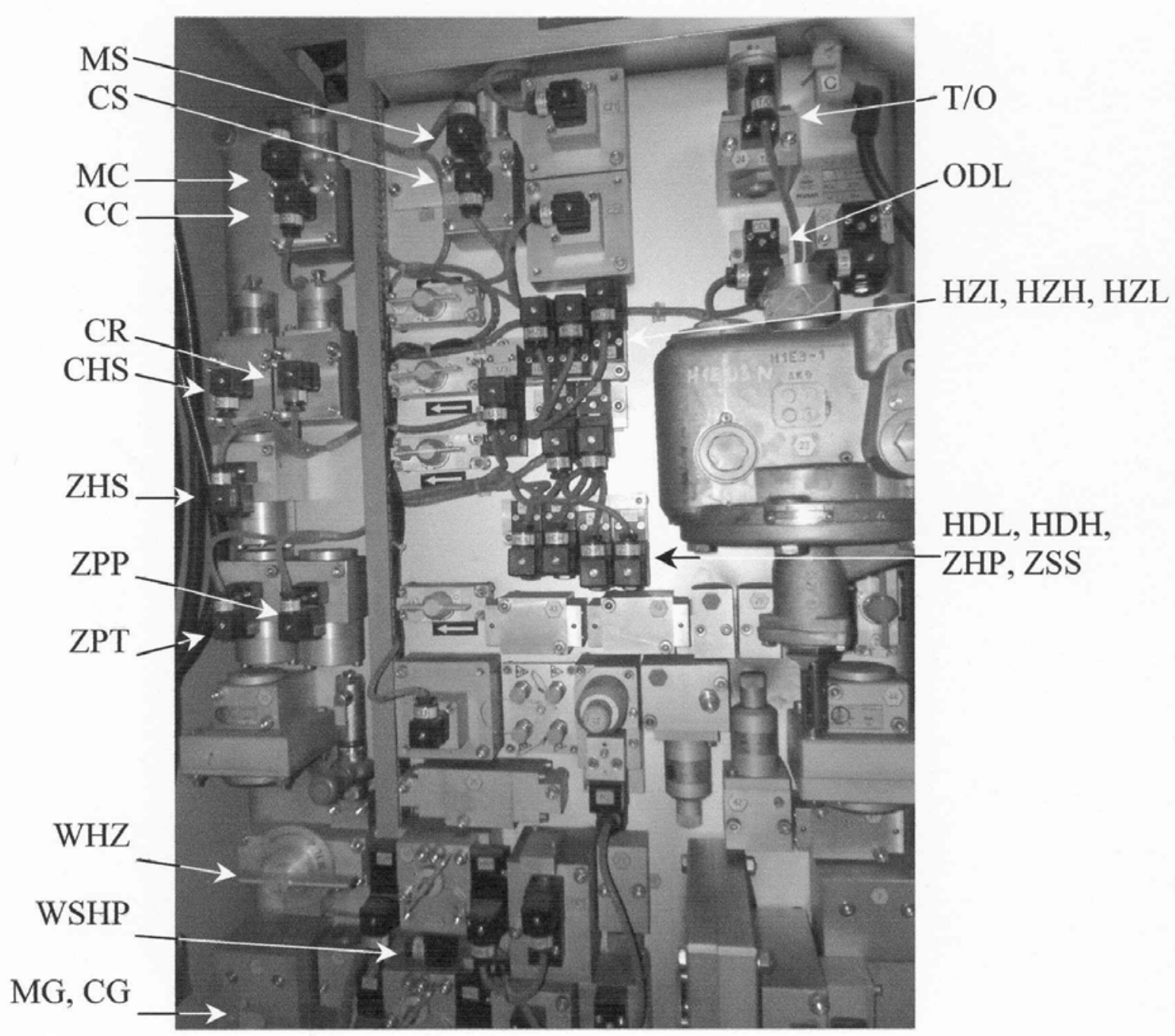

Rys. 3. Tablica pneumatyczna zmodernizowanej lokomotywy ST44

- MS - przetwornik do pomiaru ciśnienia w przewodzie zasilajacym

- CS - wyłacznik ciśnieniowy sterujacy sprężarka główna lokomotywy

- MC - przetwornik do pomiaru ciśnienia w cylindrach hamulcowych

- CC - wyłacznik ciśnieniowy sterowany ciśnieniem w cylindrach hamulcowych

- $M G$ - przetwornik do pomiaru ciśnienia w przewodzie glównym

- $C G$ - wytacznik ciśnieniowy sterowany ciśnieniem w przewodzie głównym

- CR - wytacznik ciśnieniowy sterowany ciśnieniem w zbiorniku rozrzqdu

- CHS - wyłacznik ciśnieniowy sterowany ciśnieniem w siłownikach sprężynowych hamulca postojowego

- ZHS - serwozawór zasilajacy siłowniki sprężynowe hamulca postojowego

- HZI, HZH, HZL - zawory inicjujace hamowanie stużbowe i luzowanie hamulca zespolonego

- HDL, HDH - zawory inicjujace hamowanie hamulcem dodatkowym i luzowanie tego hamulca

- T/O - zawór umożliwiajacy wybór dlugich albo krótkich czasów napelniania cylindrów hamulcowych (urzadzenie nastawcze ,, Towarowy / Osobowy”)

- WHZ - zawór z sygnalizacja elektryczna odcinajacy układ sterowania hamulcem zespolonym od przewodu głównego

- WSHP - wyłacznik układu SHP i radiostopu

- ZPP - serwozawór piasecznic używanych podczas jazdy do przodu

- ZPT - serwozawór piasecznic używanych podczas jazdy do tyłu

- ODL - zawór odluźniacza elektrycznego hamulca zespolonego lokomotywy

- ZHP - zawór sterujacy hamulcem parkingowym

- ZSS - zawór inicjujacy podhamowanie przeciwpoślizgowe lokomotywy realizujacej napęd. 


\section{Funkcje realizowane przez sterownik pneumaty- ki}

Sterownik pneumatyki realizuje następujące funkcje:

- sterowanie pracą sprężarki

- sterowanie układem hamowania

- diagnostyka układu hamowania

- piaskowanie automatyczne i ręczne

- komunikacja ze sterownikiem głównym lokomotywy

- komunikacja z przenośnym komputerem diagnostycznym

- wykrywanie, sygnalizacja oraz likwidacja poślizgu.

\subsection{Sterowanie pracą sprężarki}

Sterownik pneumatyki steruje pracą sprężarki, jeżeli przełącznik wyboru rodzaju sterowania pracą sprężarki znajduje się w pozycji „A” - tryb automatyczny. Sterowanie realizowane jest w oparciu o sygnał $\mathrm{z}$ umiejscowionego na tablicy pneumatycznej przetwornika ciśnienia $\mathrm{w}$ przewodzie zasilającym (MS). Jeżeli ciśnienie to ma wartość mniejszą od ustalonego progu, to sterownik pneumatyki informuje sterownik główny lokomotywy o konieczności załączenia sprężarki. Żądanie załączenia sprężarki przesyłane jest do sterownika głównego lokomotywy sprzętowo (za pośrednictwem odpowiedniego przekaźnika), jak również po magistrali RS232/RS485. Żądanie to sterownik główny lokomotywy przesyła dalej do sterownika falownika sprężarki po magistrali CAN. Po załączeniu sprężarki sterownik główny lokomotywy przesyła zwrotnie do sterownika pneumatyki po magistrali RS232/RS485 sygnał potwierdzający załączenie sprężarki. Sygnał ten wykorzystywany jest do obliczania czasu pracy sprężarki, a jego wartość wyświetlana jest na panelu operatorskim. Jeżeli ciśnienie w przewodzie zasilającym osiagnie określoną $\mathrm{w}$ programie wartość, sterownik pneumatyki przekazuje polecenie wyłączenia sprężarki.

Stan pracy sprężarki prezentowany jest na panelu operatorskim za pośrednictwem odpowiedniej ikony. Jeżeli temperatura powietrza tłoczonego przez sprężarkę przekroczy próg $100^{\circ} \mathrm{C}$, sterownik pneumatyki generuje odpowiedni komunikat ostrzegawczy wyświetlany na panelu operatorskim. Jeżeli nastąpi przekroczenie temperatury $115^{\circ} \mathrm{C}$, sterownik pneumatyki przekazuje polecenie wyłączenia sprężarki i generuje odpowiedni komunikat ostrzegawczy wyświetlany na panelu operatorskim.

W trybie jazdy wielokrotnej sterowanie sprężarkami odbywa się na podstawie sygnałów pochodzących z lokomotywy prowadzacej. Sterownik pneumatyki lokomotywy prowadzącej wytwarza żądanie załączenia lub wyłączenia sprężarki i przesyła je do sterownika głównego tej lokomotywy, który żądanie to za pośrednictwem magistrali pociagowej przesyła dalej do sterowników głównych lokomotyw podrzędnych.

\subsection{Sterowanie ukladem hamowania}

W przypadku jazdy lokomotywy pojedynczej lub jako lokomotywy prowadzącej w trybie jazdy wielokrotnej sterownik pneumatyki wykonuje następujące zadania:

- przesyła do sterownika głównego lokomotywy prowadzącej po magistrali RS232/RS485 informację o pozycji hamowania manipulatora hamulca dodatkowego

- realizuje sterowanie zaworem podhamowania - sterowanie to realizowane jest w przypadku wystapienia poślizgu

- realizuje sterowanie serwozaworami piasecznic - sterowanie to realizowane jest po naciśnięciu przez maszynistę przycisku umiejscowionego na pulpicie lub przycisku nożnego, oraz w przypadku wystapienia poślizgu

- przesyła do sterownika głównego lokomotywy prowadzącej po magistrali RS232/RS485 informację o załączeniu przez maszynistę hamulca postojowego

- przesyła do sterownika głównego lokomotywy prowadzącej po magistrali RS232/RS485 informację o załączeniu przez maszynistę odluźniacza hamulca zespolonego lokomotywy

- steruje hamowaniem służbowym podczas trybu pracy UPZ (układu prędkości zadanej).

W przypadku jazdy lokomotywy jako lokomotywy podrzędnej w trybie jazdy wielokrotnej sterownik pneumatyki realizuje:

- sterowanie zaworem podhamowania - sterowanie to realizowane jest w przypadku wystąpienia poślizgu

- sterowanie serwozaworami piasecznic sterowanie to realizowane jest w przypadku otrzymania odpowiedniego sygnału po magistrali RS232/RS485 od sterownika głównego lokomotywy

- sterowanie zaworem hamulca postojowego sterowanie to realizowane jest $\mathrm{w}$ przypadku otrzymania odpowiedniego sygnału po magistrali RS232/RS485 od sterownika głównego lokomotywy

- sterowanie zaworem odluźniacza hamulca zespolonego - sterowanie to realizowane jest w przypadku otrzymania odpowiedniego sygnału po magistrali RS232/RS485 od sterownika głównego lokomotywy.

\subsection{Diagnostyka ukladu hamowania}

Sterownik pneumatyki realizuje następujące funkcje diagnostyki układu hamowania:

- diagnostyka tablicy pneumatycznej

- diagnostyka manipulatorów pulpitowych

- próby układu hamowania

- diagnostyka ilości hamowań hamulcem zespolonym. 
$\mathrm{Na}$ panelu operatorskim $\mathrm{w}$ oknie $\mathrm{z}$ danymi $\mathrm{z}$ układu hamulcowego są prezentowane następujące informacje:

- wartość ciśnienia w zbiorniku głównym (przewodzie zasilającym)

- wartość ciśnienia w przewodzie głównym

- wartość ciśnienia w cylindrach hamulcowych

- ilość godzin pracy sprężarki

- ilości hamowań hamulcem zespolonym o odpowiednio dużej intensywności hamowania (ciśnienie w cylindrach $\geq 200 \mathrm{kPa}$ ).

$\mathrm{W}$ oknie tym znajdują się również następujące przyciski:

- $\quad$ wywołania okna diagnostyki sprężarki

- wywołania okna diagnostyki hamulca

- wywołania okna diagnostyki układu przeciwpoślizgowego

- wywołania okna diagnostyki układu piaskowania

- uruchomienia poszczególnych prób układu hamowania.

\section{Diagnostyka tablicy pneumatycznej}

Wejściowe sygnały analogowe i cyfrowe otrzymywane $\mathrm{z}$ tablicy pneumatycznej oraz wyjściowe sygnały cyfrowe sterujące praca aparatów zabudowanych na tablicy, sterownik pneumatyki przesyła po magistrali RS232/RS485 do sterownika głównego lokomotywy. Wartości tych sygnałów mogą być wyświetlone na panelu operatorskim. W trybie jazdy wielokrotnej sterownik główny lokomotywy podrzędnej wysyła niektóre $\mathrm{z}$ tych sygnałów do sterownika głównego lokomotywy prowadzącej. Sygnały te mogą być następnie wyświetlone na panelu operatorskim tej lokomotywy.

\section{Diagnostyka manipulatorów pulpitowych}

Sterownik pneumatyki otrzymuje $\mathrm{z}$ kabiny prowadzącej sygnały cyfrowe o stanie:

- manipulatora hamulca zespolonego (nastawnik siły i hamowania)

- manipulatora hamulca dodatkowego

- nastawnika układu hamulcowego (służącego do ustawiania trybu pracy układu hamulcowego)

- przycisków piaskowania

- przycisku podwyższenia ciśnienia w przewodzie głównym

- przycisku odluźniacza hamulca zespolonego

- przełącznika hamulca postojowego.

Sygnały te są przesyłane po magistrali RS232/RS485 do sterownika głównego lokomotywy, który wykorzystuje je do sterowania. Wartości tych sygnałów mogą być również wyświetlone na panelu operatorskim. W trybie jazdy wielokrotnej sterownik główny lokomotywy podrzędnej wysyła niektóre z tych sygnałów do sterownika głównego lokomotywy prowadzacej, podobnie jak w przypadku diagnostyki tablicy pneumatycznej. Sygnały te mogą być następnie wyświetlone na panelu operatorskim tej lokomotywy.

\section{Próby układu hamowania}

Sterownik pneumatyki umożliwia przeprowadzenie na postoju lokomotywy:

- próby szczelności lokomotywy (PS)

- próby szczelności pociagu (PSP)

- próby hamulca zespolonego (PHZ)

- próby hamulca dodatkowego (PHD).

Przed uruchomieniem danej próby muszą być spełnione warunki jej rozpoczęcia: napełniony układ pneumatyczny lokomotywy, wyluzowany hamulec zespolony i dodatkowy oraz wybrane nastawienie hamulca „Osobowy”. Warunki te powinny trwać przez co najmniej 5 minut dla prób szczelności, a 30 sekund dla prób hamulcowych.

Próbę należy wykonywać zgodnie z komunikatami wyświetlanymi na panelu. Każdy etap próby jest automatycznie oceniany. W przypadku negatywnej oceny generowany jest odpowiedni komunikat, a próba nie jest kontynuowana i należy ją powtórzyć.

Sterownik pneumatyki uruchamia próbę szczelności lokomotywy po wybraniu przez maszynistę opcji PS na panelu operatorskim w oknie z danymi z układu hamulcowego. Diagnostyka polega na pomiarze ciśnień MS, MC i MG i porównaniu ich $\mathrm{z}$ wartościami właściwymi dla sprawnego układu hamulca.

Sterownik pneumatyki uruchamia próbę szczelności pociągu po wybraniu przez maszynistę opcji PSP na panelu operatorskim w oknie $\mathrm{z}$ danymi z układu hamulcowego, a następnie po wybraniu ilości osi pociagu (do 100 osi, od 100 do 150 osi, powyżej 150 osi) i otrzymaniu od sterownika głównego lokomotywy po magistrali RS232/RS485 informacji o liczbie lokomotyw prowadzących skład (1, 2 lub 3 lokomotywy). Diagnostyka polega na pomiarze czasów spadku ciśnień MS, MC i MG i porównaniu ich z wartościami właściwymi dla sprawnego układu hamulca.

Sterownik pneumatyki uruchamia próbę hamulca zespolonego po wybraniu przez maszynistę opcji PHZ na panelu operatorskim w oknie z danymi z układu hamulcowego. Oceniane są w kolejności następujące etapy próby: 1-szy stopień hamowania, 1-sze pogłębienie hamowania, 2-gie pogłębienie hamowania, hamowanie pełne, wstępny stopień luzowania, pogłębienie luzowania, luzowanie całkowite, hamowanie nagłe, luzowanie po hamowaniu nagłym. Diagnostyka polega na pomiarze ciśnień MS, MC, MG i porównaniu ich $\mathrm{z}$ wartościami właściwymi dla sprawnego układu hamulca. Przykładowe przebiegi ciśnień podczas próby hamulca zespolonego przedstawione są na rysunku 4. 


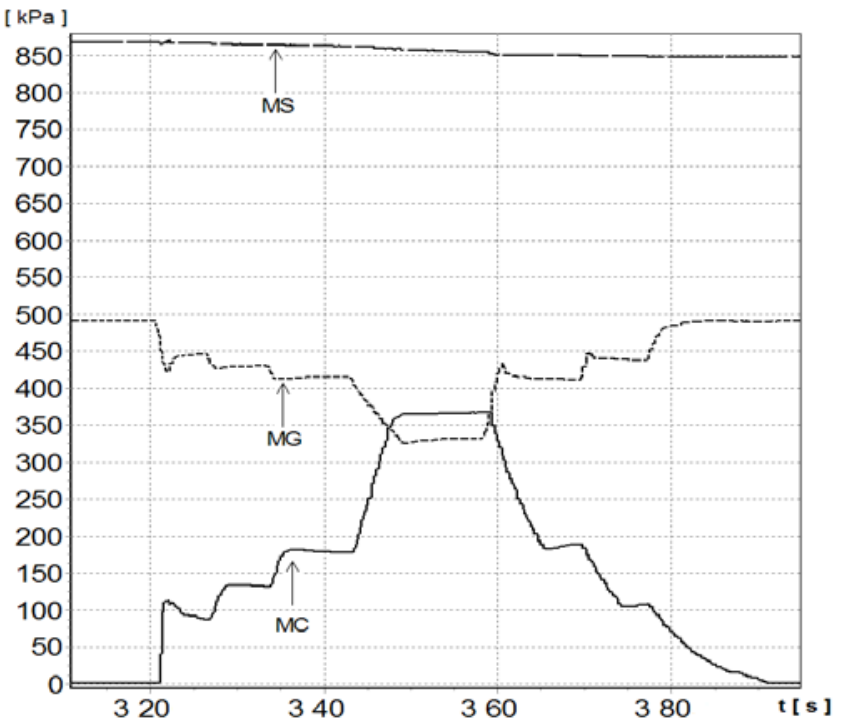

Rys 4. Przebiegi ciśnień w funkcji czasu podczas próby hamulca zespolonego

Sterownik pneumatyki uruchamia próbę hamulca dodatkowego po wybraniu przez maszynistę opcji PHD na panelu operatorskim $\mathrm{w}$ oknie $\mathrm{z}$ danymi $\mathrm{z}$ układu hamulcowego. Oceniane sa w kolejności następujące etapy próby: 1-szy stopień hamowania, 1-sze pogłębienie hamowania, 2-gie pogłębienie hamowania, hamowanie pełne, wstępny stopień luzowania, pogłębienie luzowania oraz luzowanie całkowite. Diagnostyka polega na pomiarze ciśnień MS, MC, MG i porównaniu ich $\mathrm{z}$ wartościami właściwymi dla sprawnego układu hamulca. Przykładowe przebiegi ciśnień podczas próby hamulca dodatkowego przedstawione są na rysunku 5.

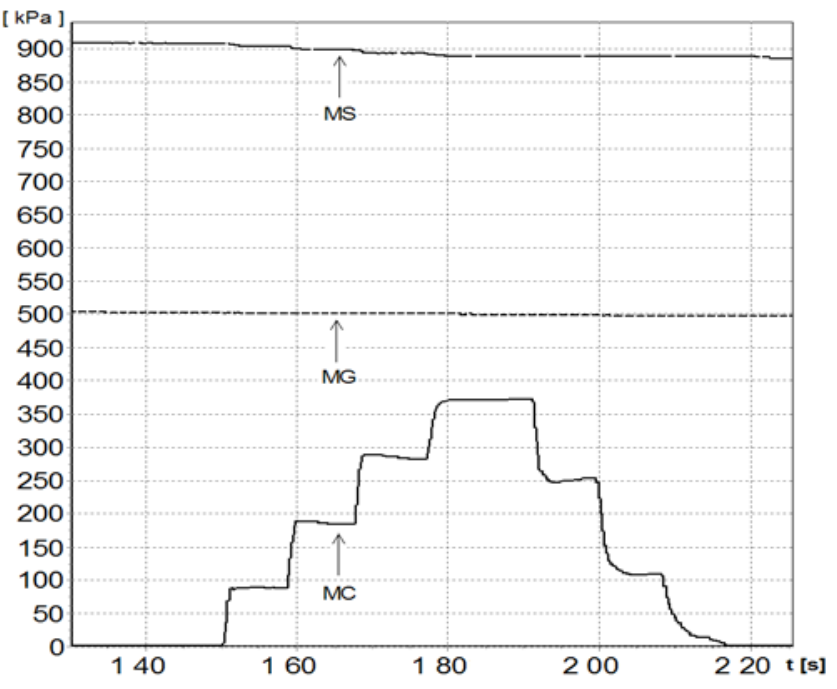

Rys 5. Przebiegi ciśnień w funkcji czasu podczas próby hamulca dodatkowego
Diagnostyka ilości hamowań hamulcem zespolonym

Sterownik pneumatyki zlicza i zapisuje do pamięci wszystkie hamowania hamulcem zespolonym (dla prędkości $\mathrm{v} \geq 2 \mathrm{~km} / \mathrm{h}$ ), które trwają dłużej niż $4 \mathrm{~s}$ i są o odpowiedniej sile hamowania powodującej wzrost ciśnienia w cylindrach hamulcowych $\geq 200 \mathrm{kPa}$. Liczba hamowań spełniających te warunki przesyłana jest do sterownika głównego lokomotywy w celu wyświetlenia na panelu operatorskim.

\subsection{Piaskowanie automatyczne i ręczne}

Sterownik pneumatyki steruje zaworami piasecznic $\mathrm{w}$ trybie ręcznym oraz $\mathrm{w}$ trybie automatycznym. $\mathrm{W}$ trybie ręcznym po naciśnięciu przycisku ,piaskowanie". W trybie automatycznym po wykryciu przez sterownik pneumatyki poślizgu w czasie jazdy lub hamowania. W tym przypadku piaskowanie trwa do momentu zlikwidowania poślizgu.

\subsection{Komunikacja ze sterownikiem głównym loko- motywy}

W trakcie pracy systemu sterowania lokomotywy sterownik pneumatyki przesyła do sterownika głównego lokomotywy ramkę 30 znakową zawierającą 26 bajtów sygnałów sterujących i diagnostycznych oraz komunikatów. Zwrotnie sterownik główny lokomotywy przesyła do sterownika pneumatyki ramkę 7 znakową zawierającą 3 bajty sygnałów sterujących.

Transmisja danych pomiędzy sterownikiem pneumatyki a sterownikiem głównym lokomotywy odbywa się za pośrednictwem konwertera RS 232 / RS 485 firmy ICP CON typu i-7520R pracującego $\mathrm{w}$ trybie HALF DUPLEX z prędkością 38400 bitów / s.

\subsection{Komunikacja $z$ komputerem serwisowym (dia- gnostycznym)}

Komunikacja sterownika pneumatyki z komputerem serwisowym odbywa się za pośrednictwem drugiego interfejsu RS 232 również z prędkością 38400 bitów / s.

Diagnostykę „on-line” sterownika pneumatyki umożliwia oprogramowanie „CAP 1131” firmy Selectron Systems AG zgodne z normą IEC 61131-3 [8]. Istnieje również możliwość wizualizacji i gromadzenia danych diagnostycznych na dysku komputera serwisowego za pośrednictwem programu „DIAGNOSTYKA On-line” opracowanego w IPS [2].

\subsection{Wykrywanie, sygnalizacja oraz likwidacja po- ślizgu}

\subsubsection{Wprowadzenie}

Jeżeli moment hamujący zestaw kołowy przekroczy wartość dopuszczalna, ograniczoną istniejącymi warunkami przyczepności, zestaw wpada w poślizg. Jeżeli nie zostaną przeprowadzone czynności zaradcze, w krótkim czasie koła zestawu zostają zablokowane. Zablokowanie kół ma dwie zasadnicze 
negatywne konsekwencje. Po pierwsze, w momencie gdy koło zostaje zablokowane siła hamowania ustala się na stałym, niskim poziomie. Uniemożliwia to skuteczne zahamowanie pojazdu szynowego. Po drugie, pojazd pozostaje w ruchu, więc zablokowane koło ślizga się po szynie, w konsekwencji czego może dojść do powstania ,płaskich miejsc” na powierzchni tocznej kół. Jeżeli z kolei moment napędzający koła przy rozruchu przekroczy wartość dopuszczalną, ograniczoną istniejącymi warunkami przyczepności, zestaw również wpada $\mathrm{w}$ poślizg, co powoduje znaczne zwiększenie prędkości obrotowej kół. Powoduje to $\mathrm{z}$ kolei spadek współczynnika przyczepności i obniżenie siły napędowej oddziałującej na tor. W efekcie ruszenie pociagu w warunkach obniżonej przyczepności może okazać się utrudnione lub wręcz niemożliwe. W związku z powyższym nowoczesne pojazdy szynowe wyposażane są w układy przeciwpoślizgowe mające na celu ochronę kół przed poślizgiem oraz zapewnienie możliwie najwyższej w danych warunkach poślizgu siły hamowania.

Jedną z funkcji mikroprocesorowego sterownika pneumatyki dla zmodernizowanej lokomotywy ST44 jest sterowanie układem wykrywania i likwidacji poślizgu, nazywanego również układem przeciwpoślizgowym. Opis tego układu przedstawiony jest w [3 i 4]. Układ przeciwpoślizgowy wykrywa poślizg przy rozruchu i hamowaniu, likwiduje poślizg przy hamowaniu, oraz współpracuje ze sterownikiem lokomotywy przy likwidacji poślizgu przy rozruchu.

Podczas poślizgu przy rozruchu układ przekazuje informację do sterownika lokomotywy oraz uruchamia selektywne podhamowanie osi. Podczas poślizgu przy hamowaniu układ poprzez odpowiednie wysterowanie zaworów upustowych zmniejsza moment hamujący zastawy kołowe będące w poślizgu, następnie po odzyskaniu przyczepności odpowiednio zwiększa ten moment umożliwiając hamowanie pojazdu.

\subsubsection{Budowa i zasada dzialania ukladu przeciw- poślizgowego}

Lokomotywa spalinowa posiada dwa trzyosiowe wózki, wyposażone w hamulce typu klockowego. Każdy z wózków lokomotywy posiada cztery cylindry hamulcowe. Każdy cylinder uruchamia klocki jednego koła zewnętrznego oraz jeden klocek koła wewnętrznego. Pomiar prędkości dokonywany jest dla każdej osi oddzielnie. Każda para cylindrów jednej strony wózka posiada wspólny zawór przeciwpoślizgowy (po dwa zawory na wózek). Są to zawory upustowe typu 7 ZH 51 produkcji IPS „TABOR”. Każdy zawór przeciwpoślizgowy zawiera zaworek odcinający oraz zaworek odpowietrzajacy. Zawory upustowe umieszczone są pomiędzy zaworem rozrządczym a cylindrami i są sterowane niezależnie od siebie; każdy z nich posiada własne sygnały sterujące ( $\mathrm{ZO}$ - sygnał sterujący zaworkiem odcinającym i ZL - sygnał sterujący zaworkiem odpowietrzającym). Poprzez odpowiednie wysterowanie zaworów przeciwpoślizgowych można sterować ciśnieniem w cylindrach hamulcowych, a przez to momentem hamującym zestawy kołowe. Schemat układu hamulcowego z urządzeniami układu przeciwpoślizgowego przedstawiony jest na rys. 6 .

Do pomiaru prędkości zastosowano czujniki firmy DAKO. Są to czujniki reluktancyjne, więc dodatkowo zastosowano wzmacniacze sygnałów WSL-5. Wzmacniacz jest trójkanałowy, więc na jeden wózek zastosowano jeden wzmacniacz. Przekształcone w ten sposób sygnały z czujników podawane są na wejścia modułów licznikowych sterownika układu przeciwpoślizgowego. $\mathrm{Na}$ ich podstawie obliczane są prędkości kątowe kół pojazdu, które razem z wartością średnic kół pozwalają na obliczenie chwilowych wartości prędkości obwodowych poszczególnych kół.

$\mathrm{Na}$ podstawie sygnałów $\mathrm{z}$ czujników prędkości CP1, CP2, CP3, CP4, CP5 i CP6 oraz sygnałów o stanie lokomotywy (hamowanie i jazda) sterownik układu przeciwpoślizgowego wykrywa poślizgi występujące w czasie hamowania i jazdy lokomotywy. W zależności od potrzeby sterownik steruje zaworami upustowymi (sygnały ZO1, ZL1, ZO2, ZL2, ZO3, ZL3, ZO4, ZL4) oraz zaworem podhamowania (sygnał PHS), wytwarza sygnał piaskowania (Piask), używany w zależności od kierunku jazdy do wysterowania odpowiednich zaworów piaskowania, a także wysyła do sterownika lokomotywy sygnał (PJ) informujący o wystąpieniu poślizgu przy jeździe.

\subsubsection{Budowa i zasada działania sterownika układu przeciwpoślizgowego}

Schemat blokowy przedstawiający działanie sterownika układu przeciwpoślizgowego przedstawiony jest na rys. 7 . W ramach realizacji układu przeciwpoślizgowego sterownik wykonuje następujące funkcje:

1. pomiar prędkości obrotowych wszystkich 6 osi lokomotywy

2. testowanie czujników prędkości

3. obliczanie współczynników korekcji średnic kół

4. wyznaczanie prędkości i przyspieszeń obwodowych kół

5. wyznaczanie prędkości referencyjnej

6. wykrywanie i likwidację poślizgu przy hamowaniu

7. wykrywanie poślizgu przy rozruchu i przekazywanie informacji o nim do sterownika lokomotywy

8. selektywne podhamowanie zestawów kołowych. 


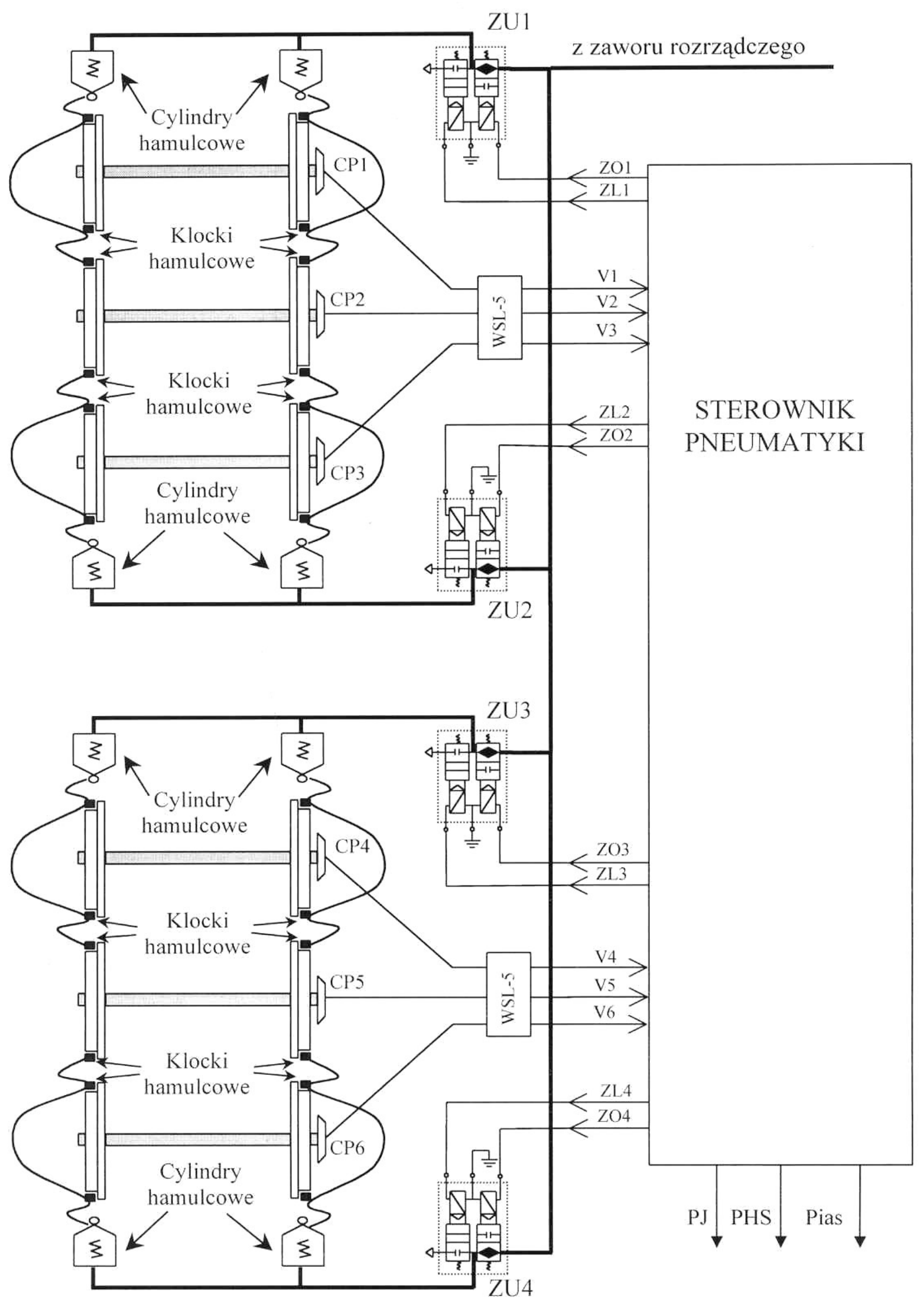

Rys. 6. Schemat blokowy układu przeciwpoślizgowego CP - czujniki prędkości, ZU1...ZU4 - zawory upustowe, WSL-5 - wzmacniacze sygnałów 


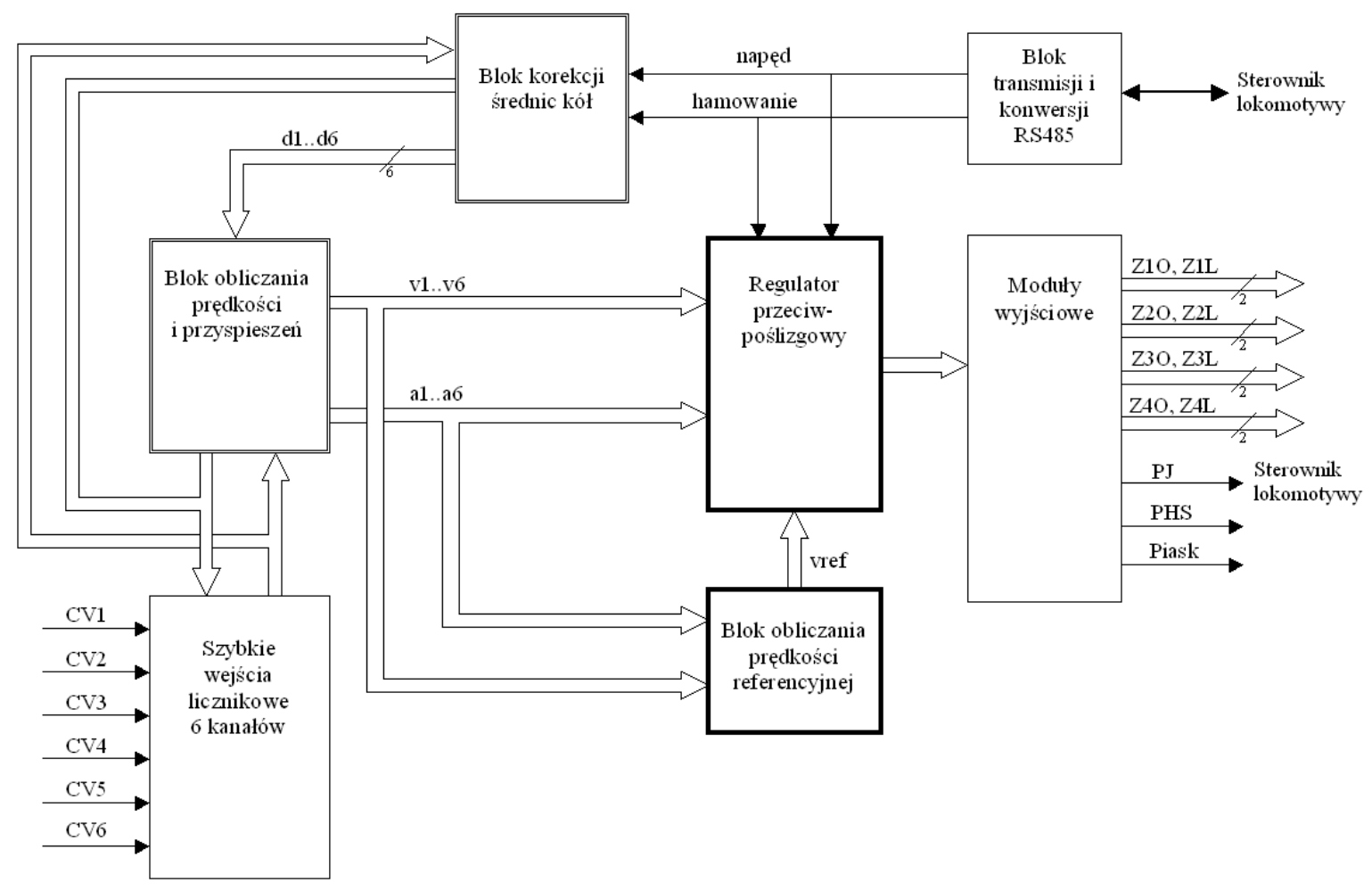

Rys. 7. Programowo-sprzętowy schemat blokowy działania układu przeciwpoślizgowego

\section{a) Pomiar prędkości obrotowych osi}

W maźnicy każdej osi wózka zabudowany jest czujnik prędkości FE 1.4 firmy DAKO. Sygnały z tych czujników są sygnałami sinusoidalnymi o częstotliwości i amplitudzie zależnych od prędkości obrotowej osi. Sygnały te podawane są na wzmacniacze sygnałów WSL-5 produkcji IPS „TABOR”, które przetwarzaja je do postaci ciagów impulsów o stałej amplitudzie +24 V DC i zmiennej częstotliwości. Otrzymane w ten sposób ciagi impulsów podawane są na wejścia liczników częstotliwości modułów mikroprocesorowych CPU 727-CT. W oparciu o zmierzoną częstotliwość wyznaczana jest prędkość obrotowa każdej osi.

\section{b) Testowanie czujników prędkości}

Poprzez porównanie wartości prędkości obrotowej wszystkich osi, przeprowadzane podczas wybiegu lokomotywy, wykrywane jest ewentualne uszkodzenie czujników prędkości. W sytuacji wykrycia uszkodzenia czujnika, wyłączana jest ochrona przeciwpoślizgowa dla osi, której prędkość obrotową mierzy uszkodzony czujnik. Informacja o uszkodzeniach czujników pojawia się na panelu operatorskim.

c) Obliczanie współczynników korekcji średnic kół

Obliczanie prędkości obwodowych kół lokomotywy wymaga znajomości ich rzeczywistej średnicy. Srednica nowego koła wynosi $1,05 \mathrm{~m}$, ale podczas jazdy koła pojazdów trakcyjnych mogą zużywać się nierównomiernie tak, że powstają różnice $\mathrm{w}$ średnicach kół. Rozbieżności średnic kół poszczególnych osi, spowodowane zużyciem kół powodują, że obliczone prędkości i przyspieszenia osi odbiegają od rzeczywistych wartości, co powoduje niewłaściwą pracę układu przeciwpoślizgowego. Dlatego też, w celu ujednolicenia wskazań prędkości, należy wprowadzić współczynnik korekcji związany ze zużyciem kół danej osi. Korekcja średnicy kół dokonywana jest po każdym włączeniu napięcia zasilania sterownika. Przeprowadza się ją na podstawie równoczesnych pomiarów sygnałów z wszystkich 6 osi dokonywanych w warunkach zapewniających brak zakłóceń pomiaru, tzn. jeżeli przez określony czas spełnione są następujące warunki:

- lokomotywa porusza się na wybiegu

- prędkość lokomotywy znajduje się w ustalonym zakresie

- przyspieszenie lokomotywy znajduje się w ustalonym zakresie.

Wówczas na podstawie przeprowadzonych pomiarów wyznacza się współczynniki korekcji średnic względem największej średnicy koła. Z uwagi na fakt, że średnice kół po przetoczeniach mogą różnić się od średnicy koła fabrycznie nowego nawet do $8 \%$, po każdym przetoczeniu kół do sterownika układu przeciwpoślizgowego należy wprowadzić wartość maksymalnej średnicy (za pośrednictwem panelu operatorskiego przez personel warsztatowy). Wartość ta przesyłana jest ze sterownika lokomotywy do sterownika układu przeciwpoślizgowego. Współczynniki te sa następnie wykorzystywane do korekcji średnic kół wyznaczonych na podstawie pomiarów częstotliwości 
impulsów z czujników prędkości. Współczynniki zapisywane są do pamięci nieulotnej sterownika, co umożliwia zastosowanie korekcji nawet wówczas, gdy podczas danej jazdy nie zaistnieją warunki do przeprowadzenia korekcji. Jeżeli korekcja zostanie dokonana, wówczas nowe wartości współczynników zapisywane sa w miejsce starych.

\section{d) Wyznaczanie prędkości i przyspieszeń obwodo- wych kól}

W oparciu o pomierzone prędkości kątowe osi oraz wyznaczone aktualne wartości średnic kół obliczane są wartości prędkości obwodowych kół. W oparciu o wartości bieżące oraz wartości zapamiętane z poprzednich pomiarów wyznaczane są dla wszystkich osi wartości przyspieszeń obwodowych kół.

\section{e) Wyznaczanie prędkości referencyjnej}

W oparciu o obliczone chwilowe wartości prędkości i przyspieszeń wszystkich kół obliczana jest chwilowa wartość prędkości referencyjnej, będącej estymowaną prędkością postępową lokomotywy. Sposób wyznaczania prędkości referencyjnej jest następujący:

Podczas hamowania jako prędkość referencyjna przyjmowana jest największa z prędkości osi. Jeżeli opóźnienie wszystkich osi przekroczy wartość dopuszczalnego opóźnienia pociagu (w przypadku poślizgu przy hamowaniu wszystkich osi), wówczas prędkość referencyjna jest wyznaczana obliczeniowo. W przypadku, gdy czas obliczeniowego wyznaczania prędkości referencyjnej przekroczy zadaną wartość graniczną (krańcowo złe warunki przyczepności), następuje celowe obniżenie ciśnienia w cylindrze hamulcowym osi o największej prędkości w celu podniesienia jej prędkości powyżej obliczeniowej wartości prędkości referencyjnej. Proces ten trwa dopóki prędkość dowolnej osi nie podniesie się powyżej prędkości referencyjnej wyznaczonej obliczeniowo. $\mathrm{Na}$ czas obniżenia ciśnienia zawiesza się działanie układu przeciwpoślizgowego dla tej osi.

Podczas jazdy i wybiegu jako prędkość referencyjna przyjmowana jest najmniejsza z prędkości osi. Jeżeli przyspieszenie wszystkich osi przekroczy wartość dopuszczanego przyspieszenia pociagu (w przypadku poślizgu przy rozruchu wszystkich osi), wówczas prędkość referencyjna jest wyznaczana obliczeniowo.

\section{f) Wykrywanie i likwidacja poślizgu przy hamowa- niu}

Dla każdej osi obliczana jest różnica prędkości referencyjnej i prędkości kół danej osi. Przez porównanie wartości różnic prędkości oraz przyspieszeń osi z ustalonymi wartościami krytycznymi wykrywany jest poślizg przy hamowaniu. Po rozpoczęciu poślizgu przy hamowaniu przyczepność może zostać odzyskana poprzez zmniejszenie momentu hamującego. Po odzyskaniu przyczepności należy ponownie zwiększyć moment hamujący, aby skutecznie zahamować pojazd. W ramach likwidacji poślizgu sterownik generuje sygnały sterujące cewki zaworów upustowych (sygnały ZO1, ZL1, ZO2, ZL2, ZO3, ZL3, ZO4, ZL4 rys. 1), co umożliwia upuszczanie powietrza $\mathrm{z}$ cylindrów hamulcowych, (powodując zmniejszanie momentu hamującego), utrzymywanie wartości ciśnienia na stałym poziomie lub popełnianie cylindrów hamulcowych, (powodując zwiększanie momentu hamującego). Jednocześnie załączony zostaje zawór piaskowania (sygnał Piask). Stany pracy zaworów przeciwpoślizgowych pokazane są w tabeli 1 .

Stany pracy zaworów przeciwpoślizgowych
\begin{tabular}{|c|c|c|l|}
\hline Stan & ZL & ZO & \multicolumn{1}{|c|}{ Tabela 1} \\
\hline 1 & 0 & 0 & normalne napełnianie cylindrów \\
\hline 2 & 1 & 1 & $\begin{array}{l}\text { odcięcie zasilania powietrzem i odpowietrza- } \\
\text { nie cylindrów }\end{array}$ \\
\hline 3 & 0 & 1 & $\begin{array}{l}\text { odcięcie zasilania powietrzem bez odpowie- } \\
\text { trzania cylindrów }\end{array}$ \\
\hline 4 & 1 & 0 & stan zabroniony \\
\hline
\end{tabular}

gdzie: $Z L$ - zawór odpowietrzajacy, ZO - zawór odcinajacy, 0 - brak napięcia, 1 - podanie napięcia na cewkę zaworu.

\section{Znaczenie poszczególnych stanów zaworu:}

- w stanie 1 cylinder hamulcowy jest podłączony bezpośrednio do zaworu rozrządczego, więc ciśnienie w nim narasta

- w stanie 2 zasilanie cylindra powietrzem jest odcięte i jednocześnie jest on otworzony do atmosfery, w konsekwencji czego następuje odpowietrzenie cylindra

- w stanie 3 zasilanie cylindra powietrzem jest odcięte, ale nie jest on odpowietrzany, w związku z czym ciśnienie w cylindrze utrzymywane jest na stałym poziomie

- $\operatorname{stan} 4$ jest stanem zabronionym, ponieważ spowodowałby on odpowietrzenie systemu pneumatycznego układu hamulcowego.

g) Wykrywanie i sygnalizacja poślizgu przy rozruchu

Wykrywanie poślizgu przy rozruchu odbywa się w analogiczny sposób do opisanego wykrywania poślizgu przy hamowaniu, przez przeprowadzenie dla każdej osi porównania różnicy prędkości osi i jej przyspieszenia $\mathrm{z}$ ustalonymi wartościami krytycznymi.

Gdy zostanie wykryty poślizg podczas rozruchu, sterownik pneumatyki wysyła do sterownika lokomotywy sprzętowy binarny sygnał PJ, na podstawie którego sterownik lokomotywy rozpoczyna zmniejszanie prądu trakcyjnego. Jednocześnie wygenerowany zostaje sygnał piaskowania (Piask), wysterowany zostaje zawór podhamowania (sygnał PHS) oraz wysterowane zostają odpowiednie zawory przeciwpoślizgowe, co zapewnia selektywne podhamowanie zestawów kołowych. 
h) Selektywne podhamowanie zestawów kołowych

Jednocześnie bezpośrednio po wykryciu poślizgu przy jeździe sterownik układu przeciwpoślizgowego zaczyna realizować tzw. podhamowanie selektywne, polegające na tym, że na wszystkich cylindrach hamulcowych ustalane jest niewielkie ciśnienie rzędu 1 bar, a jednocześnie poprzez wysterowanie odpowiednich zaworów upustowych odcinane jest zasilanie powietrzem cylindrów dla osi, które nie są w stanie poślizgu. Powoduje to, że osie znajdujące się w stanie poślizgu są podhamowywane niewielkim ciśnieniem, co skutecznie wspomaga likwidację ich poślizgu, a jednocześnie nie ogranicza momentu napędowego tych osi, na których poślizg nie występuje.

\section{Przeprowadzone próby układu wykrywania i likwidacji poślizgu oraz ich wyniki}

W celu sprawdzenia poprawności działania układu wykrywania i likwidacji poślizgu przy hamowaniu zostały przeprowadzone próby połączone $\mathrm{z}$ rejestracją wyników. Rejestrowane były następujące sygnały: obwodowe prędkości i przyspieszenia poszczególnych osi, prędkość postępowa pojazdu oraz stany sygnałów sterujących zaworami upustowymi. Próby odbywały się poprzez przeprowadzanie hamowania $\mathrm{z}$ różnych prędkości oraz rozruchu w warunkach obniżonej przyczepności. Próby wykazały prawidłowe działanie układu. Przykładowe wyniki z badań przedstawione są na rys. 8 . Na rys 8 a przedstawione są przebiegi z próby, podczas której zestawy kołowe wpadły w poślizg z niewielką wartością opóźnienia, a na rys. $8 \mathrm{~b}$ przedstawione są przebiegi z próby, podczas której zestawy kołowe wpadły w poślizg z relatywnie dużą wartością opóźnienia. Na rys. 8 i 9 przebiegi v1...v6 oznaczają prędkości obwodowe poszczególnych zestawów kołowych lokomotywy. $\mathrm{Na}$ rys. 8a zaznaczono bezwzględny poślizg dla zestawu kołowego $\mathrm{nr} 6$ względem największej prędkości spośród wszystkich zestawów kołowych lokomotywy.

a)

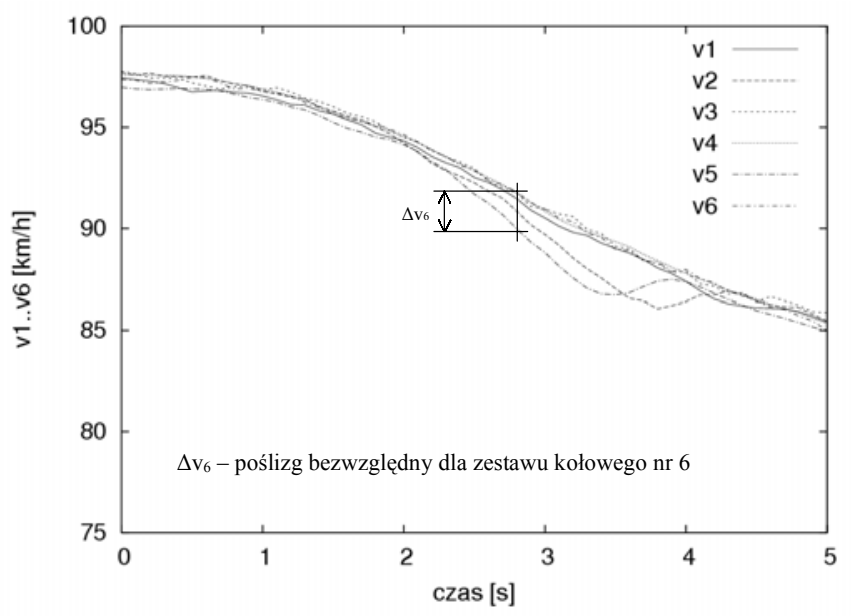

b)

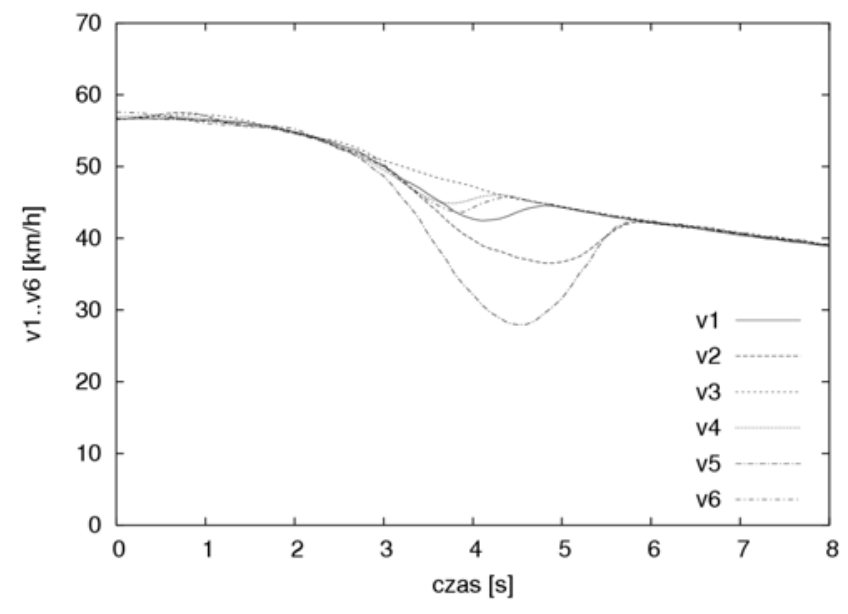

Rys. 8. Przykładowe przebiegi prędkości obwodowych zestawów kołowych w funkcji czasu podczas likwidacji poślizgu przy hamowaniu

W celu sprawdzenia działania układu wykrywania poślizgu przy rozruchu, podczas jazd próbnych rejestrowane były wielkości niezbędne do oceny poprawności działania układu, takie jak obwodowe prędkości i przyspieszenia poszczególnych kół, prędkość referencyjna, stany sygnałów sterujących zaworami upustowymi i zaworami podhamowania oraz sygnał wykrycia poślizgu przekazywany do sterownika lokomotywy. Próby wykazały prawidłowe działanie układu. Przykładowe wyniki z badań przedstawione są na rys. 9.

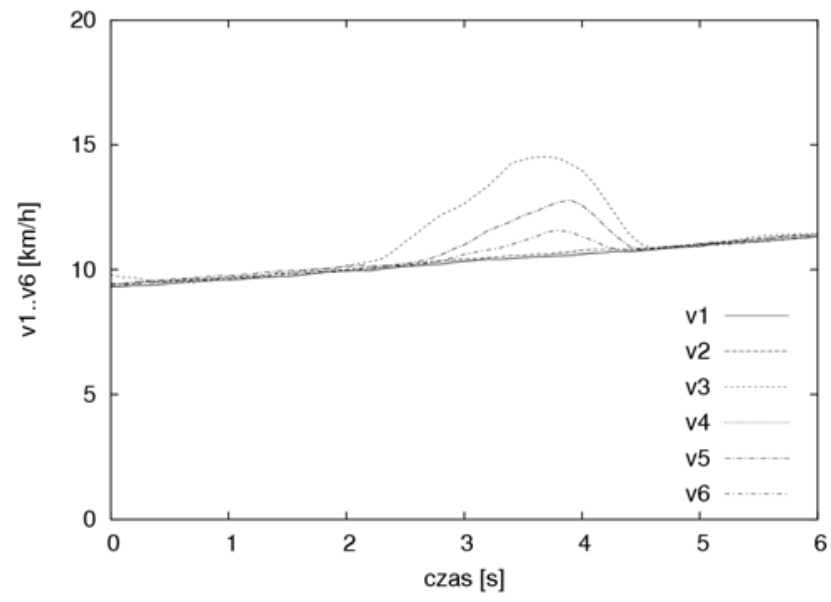

Rys. 9. Przykładowe przebiegi prędkości obwodowych zestawów kołowych w funkcji czasu podczas likwidacji poślizgu przy rozruchu

\section{Podsumowanie i wnioski}

Przedstawiony sterownik pneumatyki został wdrożony i przetestowany na dwóch zmodernizowanych lokomotywach ST44 z wynikiem pozytywnym. 
Współpraca sterownika pneumatyki ze sterownikiem lokomotywy pozwala na wyświetlanie na panelu operatorskim sygnałów wejściowych, wyjściowych i innych sygnałów diagnostycznych $\mathrm{z}$ tablicy pneumatycznej, co umożliwia szybkie wykrycie stanów awaryjnych i usunięcie usterek.

Dużą trudność w realizacji układu przeciwpoślizgowego dla lokomotywy ST44 stanowiła konfiguracja układu hamulcowego (rys. 6). Przykładowo, w przypadku poślizgu przy hamowaniu skrajnej osi wózka, w trakcie procesu likwidacji poślizgu tej osi zmniejszany jest również moment hamujący środkową oś i odwrotnie. To samo dotyczy podhamowania selektywnego podczas poślizgu przy rozruchu. Inny problem stanowią zakłócenia sygnałów z czujników prędkości, co wymagało wprowadzenia, między innymi, systemu programowych układów kondycjonujących.

Przewidywane kierunki dalszych prac związanych ze sterownikiem pneumatyki to rozbudowanie układu diagnozowania o zapamiętywanie w pamięci FLASH wybranych danych diagnostycznych poprzedzających stan awaryjny.

Przewidywane kierunki dalszych prac nad układem przeciwpoślizgowym to optymalizacja układu likwidacji poślizgu przy hamowaniu w celu maksymalnego wykorzystania przyczepności oraz udoskonalenie algorytmu obliczania prędkości referencyjnej, będącej jedną z podstawowych wielkości wejściowych do algorytmu wykrywania poślizgu zarówno przy rozruchu jak i przy hamowaniu.

\section{Literatura}

[1] Barna G., Stypka M.: Mikroprocesorowy uktad wykrywania i likwidacji poślizgu przy hamowaniu, Pojazdy Szynowe 4/2003.

[2] Haba M.: Wizualizacja i archiwizacja danych diagnostycznych z mikroprocesorowego uktadu sterowania systemem pneumatycznym zmodernizowanej lokomotywy ST44, Materiaty Konferencyjne XVII Konferencji Naukowej Pojazdy Szynowe, Kazimierz Dolny, 2006.

[3] Marciniak Z., Durzyński Z.: Projekt modernizacji lokomotyw spalinowych serii ST44, Technika Transportu Szynowego 9/2005, Łódź.

[4] Smolana A., Dylag W.: Koncepcja i realizacja modernizacji lokomotywy ST44, Technika Transportu Szynowego 9/2005, Łódź.

[5] Dokumentacja techniczna sterowników MAS-T Selectron Systems AG: The control system for rail vehicles Selectron MAS-T.

[6] EN 50155:2001 Railway applications. Electronic equipment used on rolling stock (Zastosowania kolejowe - Wyposażenie elektroniczne stosowane $w$ taborze).

[7] EN 50121-3-2:2000 Railway applications Electromagnetic compatibility - Part 32:Rolling stock - Apparatus (Zastosowania kolejowe - Kompatybilność elektromagnetyczna - Czesść 3.2: Tabor-Aparatura).

[8] IEC 61131-3 Programming Industrial Automation Systems. Concepts and Programming Languages, Requirements for Programming Systems, Aids to Decision - Making Tools (Sterowniki programowalne. Część 3: Języki programowania). 